\title{
ठOPEN ACCESS
}

Chemistry \& Material Sciences Research Journal

Vol. 2(1), pp. 1-5, January, 2020

Fair East Publishers

Journal Homepage: www.fepbl.com/index.php/cmsri

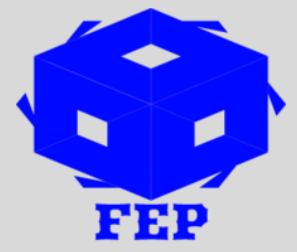

\section{SCANNING ELECTRON MICROSCOPIC ANALYSIS OF PASSIFLORA INCARNATA LINN LEAF}

\author{
Poonam Sethi ${ }^{1}$ \\ ${ }^{1}$ Assistant Professor, Guru Nanak College, (Autonomous), Chennai, India
}

*Corresponding Author: Poonam Sethi.

Corresponding Author Email: poonam123.73@ @ediffmail.com

Article Received: 12-09-19 Accepted: 30-12-19

Published: $31-01-20$

Licensing Details: Author retains the right of this article. The article is distributed under the terms of the Creative Commons Attribution-Non Commercial 4.0 License (http://www.creativecommons.org/licences/by-nc/4.0/) which permits non-commercial use, reproduction and distribution of the work without further permission provided the original work is attributed as specified on the Journal open access page.

\section{ABSTRACT}

Passiflora incarnata, commonly known as passionflower, is a fast-growing perennial vine with climbing or trailing stems. It has large, intricate flowers with prominent styles and stamens. Extrafloral glands in Passifloraceae species have aroused the interest of many researchers because of their wide morphological diversity. Hence this present work analysed the foliar trichomes on Passiflora incarnata. Scanning electron microscopy analysis was carried out. Phytochemical screening was also studied which are of taxonomic significance. Rich source of saponins, glycosides and proteins. The major phytoconstituents of this plant is Passicol, a polyacetylenic compound.

Keywords: Epidermal, Glandular, Passiflora, Stomata, Trichome, SEM..

\section{INTRODUCTION}

Medicinal plants form the backbone of traditional systems of medicine in India, mainly the three siddha, ayurvedha and unani, thousands of Indians still use plants to cure ailments. This extensive study has led intensified efforts on the documentation of ethnomedical data of medicinal plants (Dhar, Dhar, Dhawan, \& Ray, 1968). Medicinal plants are the rich source of novel drugs that forms the ingredients in traditional systems of medicine form bioactive principles and compounds in synthetic drugs (Ncube, Afolayan, \& Okoh, 2008). Passion flowers have unique floral structures, require biotic pollination. Pollinators of Passiflora include bumblebees, carpenter bees, wasps, bats, and hummingbirds . The fresh or dried leaves of passiflora are used to make a tea that is used for insomnia, hysteria, 
and epilepsy, having analgesic properties. Passionflower has sedative effects and preferred in Europe, but in 1978, the U.S. Food and Drug Administration prohibited its use in over-thecounter sedative preparations because it had not been proven safe and effective.

\section{MATERIALS AND METHOD}

The whole plant was collected from Guru Nanak College campus, Chennai of Tamil Nadu, India identified by botanist of CSMDRIA Chennai.(Figure I). Microscopical characters were studied (Trease \& Evans, 1997). Epidermal tissues were studied from paradermal sections of lamina in surface view under Scanning Electron Microscope (SEM). The leaf was dried, powdered and studied under the compound microscope.

\section{Extract Preparation}

The plant leaves were air dried and powdered. Transferred the powdered material into solvent extractor and extracted it with 95\% ethanol and aqueous solution for $72 \mathrm{~h}$. The extract was obtained as a brown gummy solid. The extract was stored at room temperature and used for phytochemical screening.

Phytochemical screening of plant extracts was done following the standard procedure by Kokate, Purohit, and Gokhale (2001) and Harbone (1998). The aqueous and ethanolic plant leaf extracts were subjected to preliminary phytochemical screening for the presence of alkaloids, quinones, resins, tannins, flavanoids, fats, saponins, phenolic compounds. The presence of more phytochemicals in Passiflora foetida indicates that it has many medicinal properties (Peach \&Tracey, 1956)

\section{I) SEM ANALYSES OF LEAF LAMINA}

\section{RESULTS}

Trichomes were clearly distinguished as unicellular twisted, glandular trichomes with flat surface and wavy anticlinal epidermal wall cells. (Figure 1-4)

\section{II) PHYTOCHEMICAL SCREENING}

Phytochemical screening revealed the presence of phenols, flavones, glycosides in the aqueous and ethanolic extract (Table 1). Presence of these phytochemical constituents might be responsible for the therapeutic properties exhibited by this plant.

\section{CONCLUSION}

The above parameters help in identifying the species and to establish the authenticity of this plant and can possibly help to differentiate the drug from its other adulterants.

\section{References}

Dhar, M. L., Dhar, M. M., Dhawan, B. N., \& Ray, C. (1968). Screening of Indian plants for biological activity - Part I. Indian Journal of Experimental Biology, 6, 232247. 
Harborne, J.B. (1998). Phytochemical method: A Guide to Modern technique of Plant Analysis (3rd edn.). Chapman and Hall: New York.

Kokate, C,K. (2005). A text book of Practical pharmacognosy (5th edn.). Vallabh Prakashan: New Delhi.

Kokate, C.K., Purohit, A.P., \& Gokhale, S.B. (2001). Carbohydrate and derived Products, drugs containing glycosides, drugs containing tannins, lipids and protein alkaloids. Text book of pharmacognosy ( $7^{\text {th }}$ edn.).

Ncube, N., Afolayan, S.A.J., \& Okoh, A.I. (2008). Assessment techniques of antimicrobial properties of natural compounds of plant origin: Current methods and future trends. African Journal of Biotechnology, 7, 1797-1806.

Peach, K., \& Tracey, M. V. (1956). Modern methods of plant analysis. Springer Verlag, Berlin.

Trease \& Evans. (1997). Pharmacognosy (14th Ed), Harcourt Brace and Company. Asia Pvt. Ltd. Singapore.

\section{TABLES}

Table 1: Phytochemical Constituents of Passiflora Leaf

\begin{tabular}{|l|c|c|}
\hline $\begin{array}{l}\text { Phytochemical } \\
\text { constituent }\end{array}$ & Aqueous extract & Ethanolic extract \\
\hline Alkaloids & + & + \\
\hline Tannin & - & + \\
\hline Saponin & - & - \\
\hline Terpenoids & + & + \\
\hline Phytosterol & - & + \\
\hline Flavonoid & + & + \\
\hline Glycosides & + & ++ \\
\hline Phlobatannins & - & + \\
\hline Carbohydrates & + & ++ \\
\hline Triterpenoids & + & + \\
\hline Quinone & - & - \\
\hline Resin & - & - \\
\hline Oil & - & - \\
\hline Steroids & - & + \\
\hline Phenol & - & + \\
\hline
\end{tabular}

Shade dried powdered material. (+) presence and (-) absence 


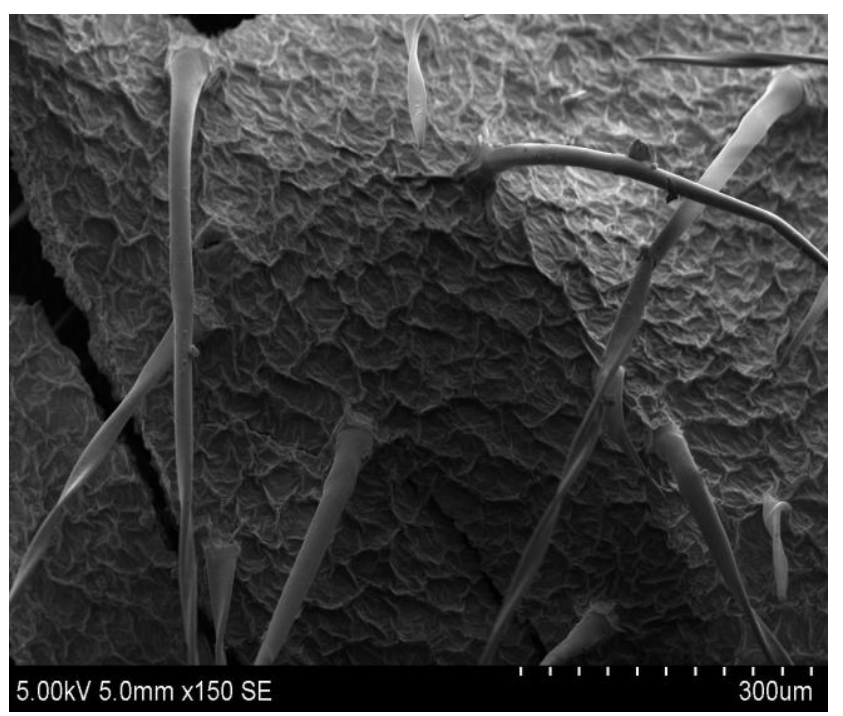

Figure 1

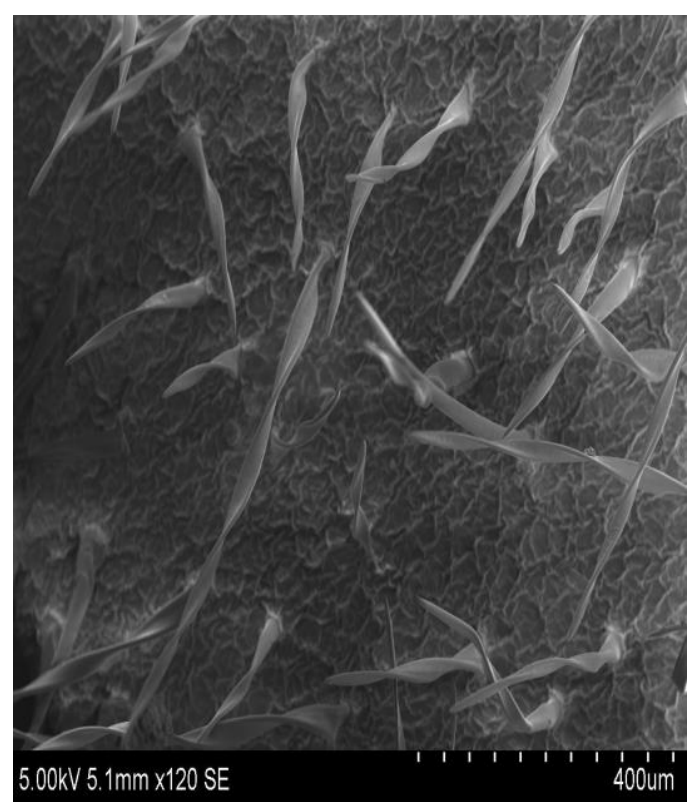

Figure 2 


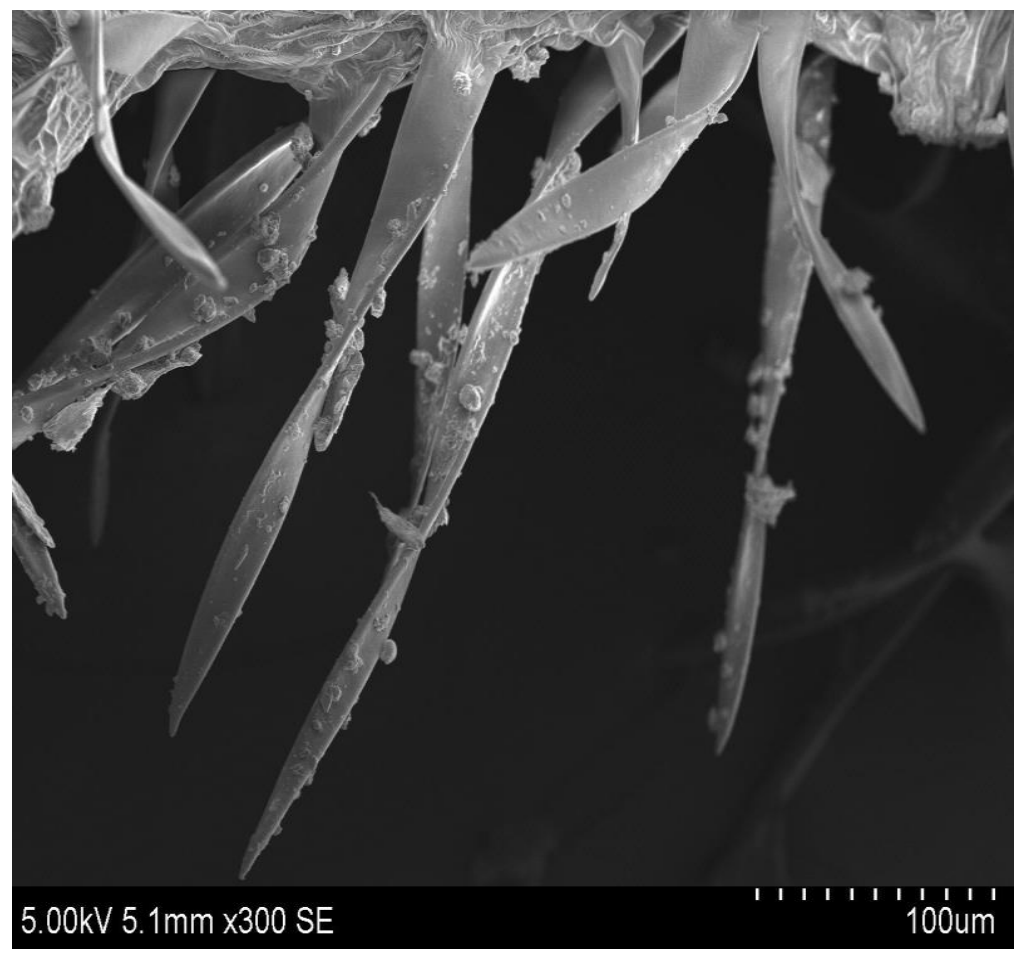

Figure 3

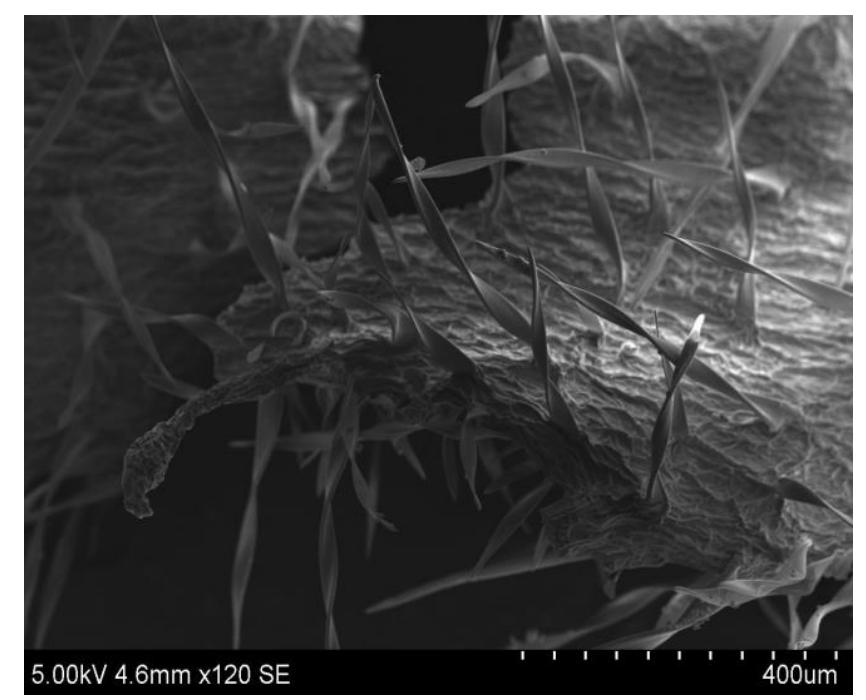

Figure 4 